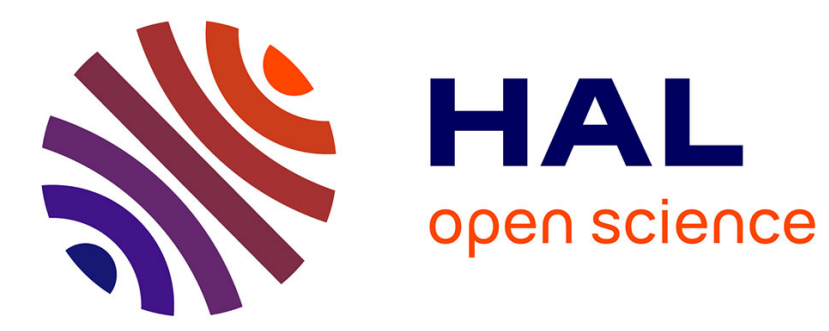

\title{
Ducropur, Ducrolloy - New chromium materials
}

\author{
H.-P. Martinz, W. Köck, T. Sakaki
}

\section{To cite this version:}

H.-P. Martinz, W. Köck, T. Sakaki. Ducropur, Ducrolloy - New chromium materials. Journal de Physique IV Proceedings, 1993, 03 (C9), pp.C9-205-C9-213. 10.1051/jp4:1993919 . jpa-00252356

\section{HAL Id: jpa-00252356 https://hal.science/jpa-00252356}

Submitted on 1 Jan 1993

HAL is a multi-disciplinary open access archive for the deposit and dissemination of scientific research documents, whether they are published or not. The documents may come from teaching and research institutions in France or abroad, or from public or private research centers.
L'archive ouverte pluridisciplinaire HAL, est destinée au dépôt et à la diffusion de documents scientifiques de niveau recherche, publiés ou non, émanant des établissements d'enseignement et de recherche français ou étrangers, des laboratoires publics ou privés. 


\title{
Ducropur, Ducrolloy - New chromium materials
}

\author{
H.-P. Martinz $\left({ }^{1}\right)$, W. Köck $\left({ }^{1}\right)$ and T. Sakaki $\left({ }^{2}\right)$ \\ ( $\left.{ }^{1}\right)$ Metallwerk Plansee, Reutte, Austria \\ $\left({ }^{2}\right)$ Tosoh Corp., Tokyo, Japan
}

\begin{abstract}
Ducropur" and "Ducrolloy" - powder metallurgically produced chromium and chromium base alloys represent a unique combination of different properties: high strength at elevated temperatures and good corrosion resistance to a large variety of chemicals as well as to hot gases. The present paper shows that Ducropur is one of the most resistant materials (better than LC-Ni) in hot caustic soda applications. Furthermore, it is shown that Ducrolloy $\mathrm{Cr} 44 \mathrm{Fe} 5 \mathrm{Al0}$.3 Ti0.5 $\mathrm{Y}_{2} \mathrm{O}_{3}$ is almost inert to boiling concentrated nitric acid. The corrosion rate is lower than that of most $\mathrm{HNO}_{3}$-resistant alloys cited in the literature. Finally, the hot air oxidation/nitridation behaviour of Ducropur can be improved by small additions of rare earth oxides

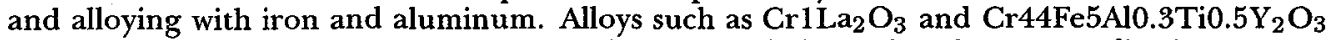
form tight protective layers and are promising materials for various hot gas applications.
\end{abstract}

\section{Introduction.}

Ducropur is the trade name of powder metallurgically produced bulk chromium. The wet corrosion and hot gas oxidation behaviour of Ducropur has been described in detail in previous papers [1, 2]. Some of those results showed very good corrosion and oxidation resistance, whereas some results - e.g. the hot gas results - indicated the necessity of an improvement of Ducropur by alloying.

In the present work the good corrosion resistance of Ducropur in hot caustic soda solutions has been verified by tests over extended periods and by direct comparison with the most important competitive materials. Similarly, the low corrosion rate of Ducropur in hot concentrated nitric acid has been evaluated and compared with competitive steel grades, cobalt and nickel base alloys, as well as with new chromium base alloys (Ducrolloys). These Ducrolloys have been developed primarily to improve the hot gas oxidation resistance of pure chromium.

\section{Experimental procedures.}

For all the tests, samples with surface areas between 2 and $20 \mathrm{~cm}^{2}$ were used. The surfaces were ground or sandblasted and degreased according to standard procedures. The duration of the tests was between one and three weeks depending on the severity of the corrosion/oxidation attack.

In the case of wet corrosion, immersion tests with renewal of the solutions each week were performed. Hot gas oxidation tests were run in chamber furnaces for hot air or in an horizontal tubular furnace for nitrogen. 
The corrosion depths and rates were determined from the specific mass changes of the samples within the testing period. Additionally metallographic evaluations with subsequent scanning electron micrography were performed in some cases.

\section{Wet corrosion - results and discussion.}

Figure 1 gives an overview of the corrosion of Ducropur in caustic soda solutions in the high concentration, high temperature range. The corrosion rates of pure chromium are very low, even lower (2 to 9 times) than those of LC (low carbon) nickel, which is one of the most favoured materials for heavy duty caustic soda applications. Figure 2 gives more detailed information about the corrosion of Ducropur, Cr50wt\% Ni and LC-Ni in $80 \% \mathrm{NaOH}$ at $150^{\circ} \mathrm{C}$. After the first week of testing all three materials showed almost equally low corrosion attack, but within the second week Cr50Ni suffered selective corrosion of the phases rich in nickel. The resulting surfaces can be seen in figure 3. Only the Cr50Ni sample is obviously corroded. A summary of experimental and literature data for $\mathrm{NaOH}$-corrosion is given in figure 4 [3-6]. The clear finding from all of these results is that the corrosion rate of the alloys decreases with increasing chromium and nickel content, chromium being the more effective element. Therefore it is not surprising that among all eligible materials Ducropur has the lowest corrosion rate.

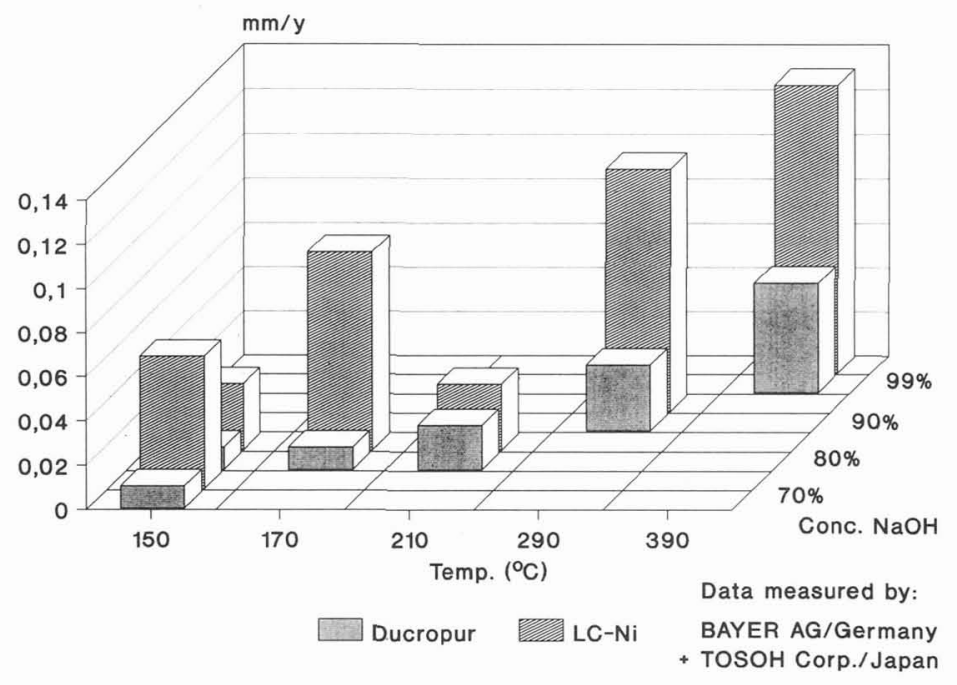

Fig. 1. - Corrosion rates of Ducropur and $\mathrm{LC}-\mathrm{Ni}$ in $\mathrm{NaOH}$ of various concentrations and temperatures.

The corrosion behaviour of Ducropur in nitric acid solutions with concentrations above $40 \%$, at temperatures up to $145^{\circ} \mathrm{C}$ for testing periods of about one week is presented in figure 5. As these corrosion rates are not low enough for an actual application of Ducropur. Various Ducrolloys with increasing Fe-content have been examined to improve their performance (Fig. 6). Of these alloys only Ducrolloy $\mathrm{Cr} 44 \mathrm{Fe} 5 \mathrm{Al} 0.3 \mathrm{Ti} 0.5 \mathrm{Y}_{2} \mathrm{O}_{3}$ proved to be capable of withstanding boiling $65 \% \mathrm{HNO}_{3}$ for three weeks. All the other alloys are more or less 


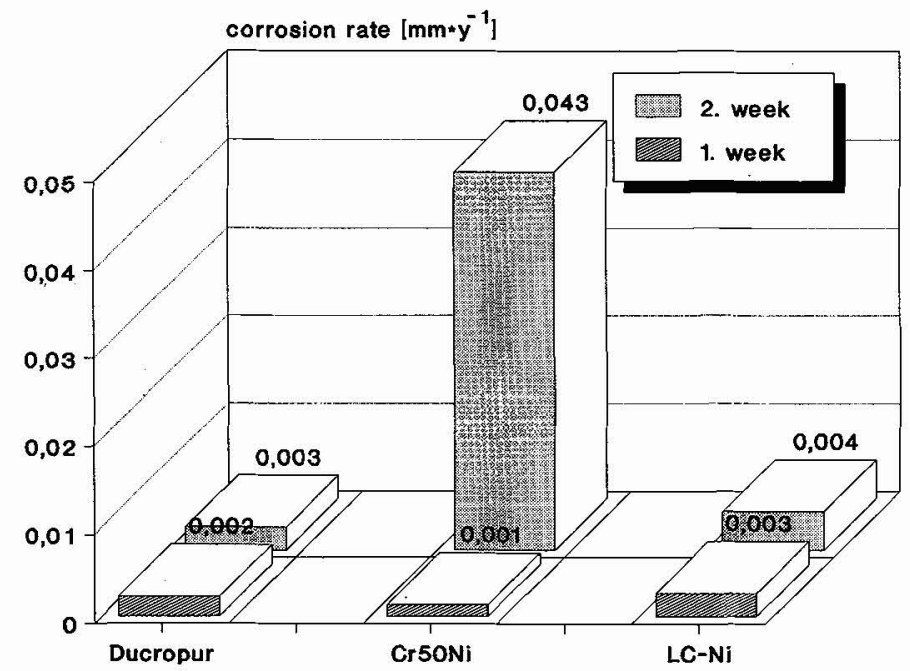

Fig. 2. - Corrosion rates of Ducropur, $\mathrm{Cr} 50 \mathrm{Ni}$ and $\mathrm{LC}-\mathrm{Ni}$ in $80 \% \mathrm{NaOH}$ at $150^{\circ} \mathrm{C}$ for 2 successive weeks.

\section{Corrosion in $80 \% \mathrm{NaOH} / 150^{\circ} \mathrm{C}$ 2 weeks}

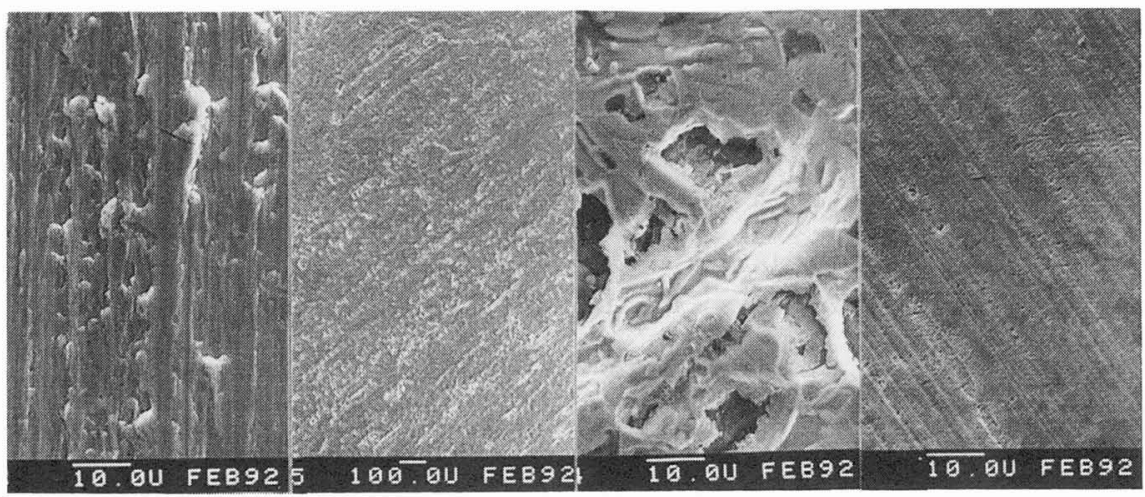

Ducropur $\times 1000$ CR50Ni $\times 48$ CR50Ni $\times 1000$ LCNi $\times 1000$

Fig. 3. - Scanning electron micrographs of Ducropur, Cr50Ni and LC-Ni surfaces after an exposure to $80 \% \mathrm{NaOH}$ at $150{ }^{\circ} \mathrm{C}$ for 2 weeks.

attacked after an induction period of one week. For comparison steel 1.4301 (Fe18Cr10Ni) has been included in the program. Figure 7 shows scanning electron micrographs and crosssections of the alloys. Experimental and literature data of corrosion in boiling $65 \% \mathrm{HNO}_{3}$ are compiled in figure 8 [7-17]. These data indicate that Ducrolloy Cr44Fe5Al0.3Ti0.5 $\mathrm{Y}_{2} \mathrm{O}_{3}$ is one of the best materials for boiling $65 \% \mathrm{HNO}_{3}$, especially when one considers that the 


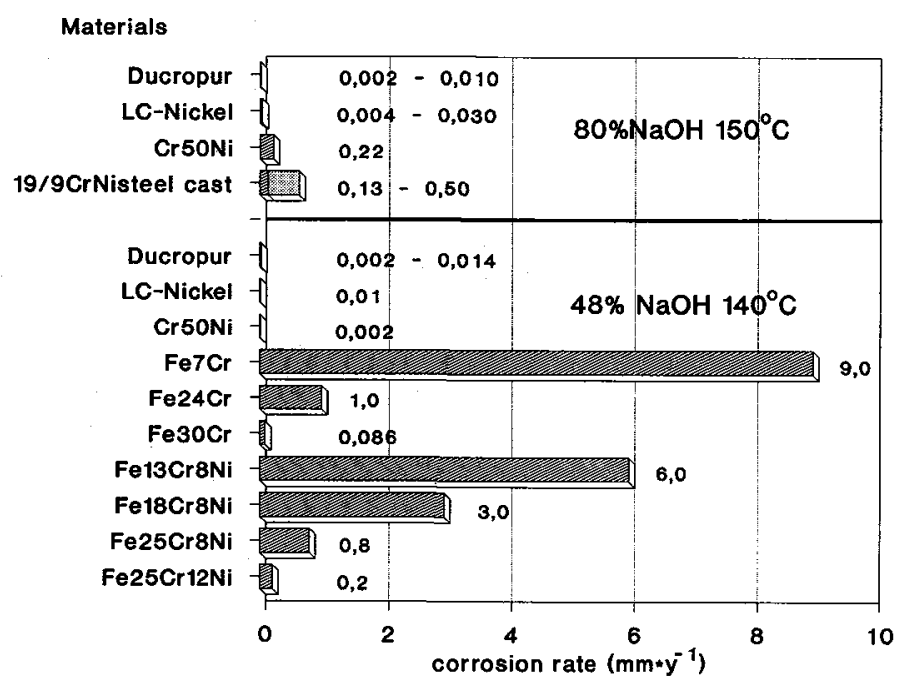

Fig. 4. - Corrosion rates of Ducropur, Cr50Ni, LC-Ni and various alloys in hot NaOH-solutions [3-6].

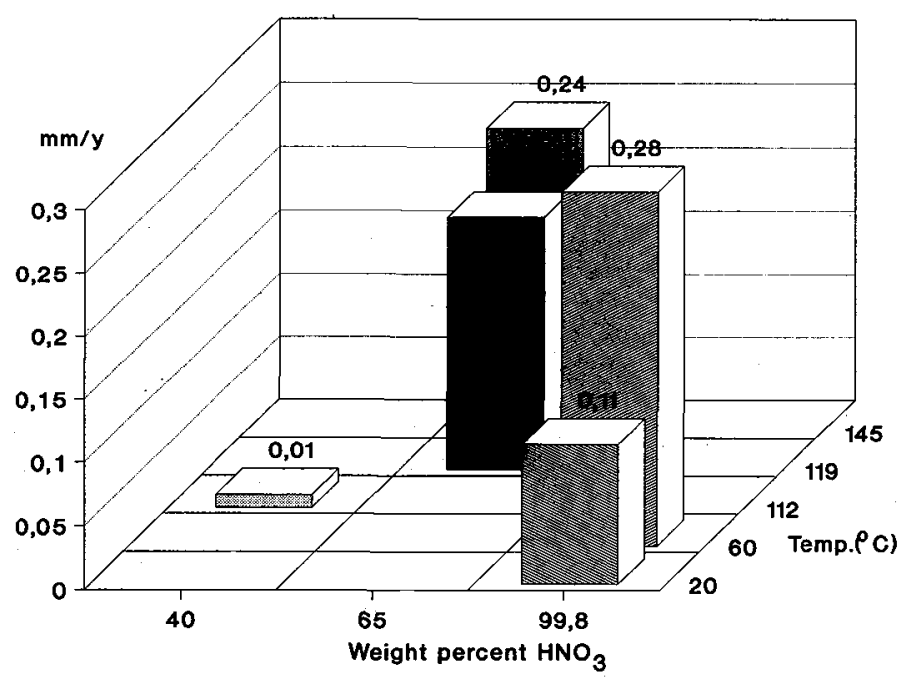

Fig. 5. - Corrosion rates of Ducropur in $\mathrm{HNO}_{3}$ of various concentrations and temperatures.

previously reported low corrosion rates of some competing materials were a result of insufficiently long exposure times.

\section{Hot gas oxidation - results and discussion.}

Figure 9 shows the results of a two step hot air oxidation test. Most of the alloys formed adherent oxide scales which did not spall off during the final cooling, except for Ducropur, 


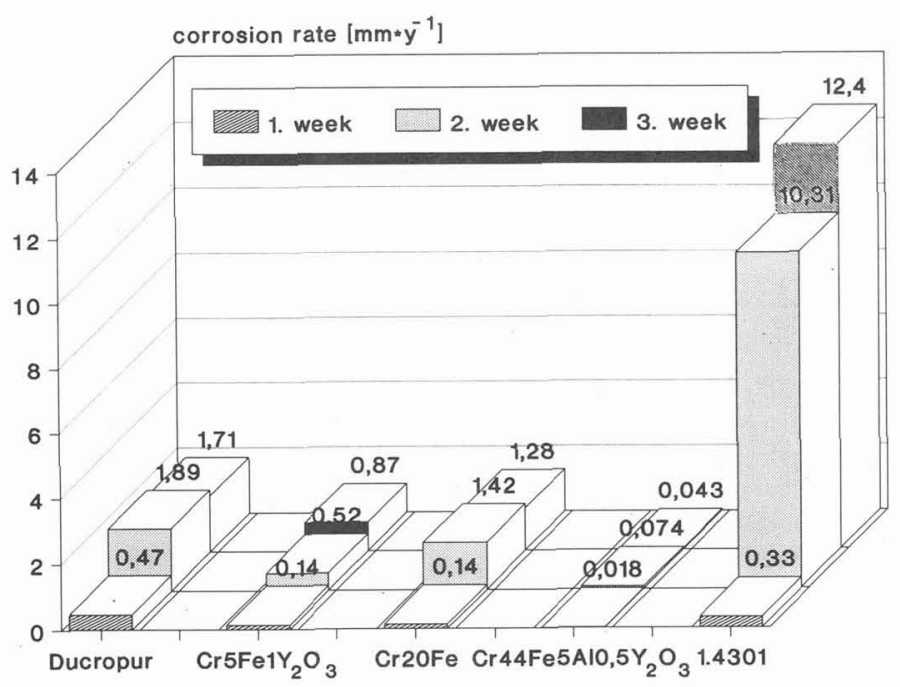

Fig. 6. - Corrosion rates of Ducropur, various Ducrolloys and steel 1.4301 in $65 \% \mathrm{HNO}_{3}$ at $119^{\circ} \mathrm{C}$ for 3 successive weeks.

Krimax (an FeCrW-allooy) and Cr50Ni. These materials took up the highest amount of hot air (bars to the right) and suffered from the greatest amount of spalling of the oxide scales (bars to the left). Electron back scattering micrographs of cross sections (Fig. 10) help to understand the results of figure 9. Ducropur, Krimax and Cr50Ni show strong internal oxidation/nitridation besides the formation of $\mathrm{Cr}_{2} \mathrm{O}_{3}$ surface layers. To some extent this can also be seen in the case of the alloys PM 1500 (ODS-Ni30Cr0.6 $\mathrm{Y}_{2} \mathrm{O}_{3}$ ), $\mathrm{Cr} 5 \mathrm{Fe} 5 \mathrm{Al}_{1} \mathrm{Y}_{2} \mathrm{O}_{3}$ and Cr5Al.

PM 1500 exhibits internal Cr oxidation whereas the Al containing Ducrolloys form $\mathrm{Cr}_{2} \mathrm{O}_{3}$ on the surface and Al-Cr-O-N needles within the bulk. PM 1000 (ODS-Ni20Cr0.6Y $\mathrm{O}_{3}$ ), $\mathrm{Cr} 5 \mathrm{Fe} 1 \mathrm{Y}_{2} \mathrm{O}_{3}$ and $\mathrm{Cr} 1 \mathrm{La}_{2} \mathrm{O}_{3}$, all three alloys being chromia formers, oxidized rather slowly and formed an adherent oxide scale.

PM 2000 (ODS-Fe20Cr5.5Al-0.5Ti0.5 $\mathrm{Y}_{2} \mathrm{O}_{3}$ ) and the two Ducrolloys with a high iron content are alumina formers (with some surface layers of $\mathrm{FeCr}$ oxides), and performed well in hot air at $1000^{\circ} \mathrm{C}$.

\section{Conclusion.}

The resistance of pure chromium (Ducropur) to hot caustic soda attack was verified in this work. The corrosion rates are lower than those of low carbon nickel. In hot highly-concentrated nitric acid solutions, Ducropur suffers from relatively aggresive corrosion starting at the grain boundaries. Ducrolloy $\mathrm{Cr} 5 \mathrm{Fe} 1 \mathrm{Y}_{2} \mathrm{O}_{3}$ behaves much better, presumably because of a more stable stable chromia passivation layer. The most resistant alloy proved to be Ducrolloy $\mathrm{Cr} 44 \mathrm{Fe} 5 \mathrm{Al} 0.3 \mathrm{Ti0} .5 \mathrm{Y}_{2} \mathrm{O}_{3}$ which is capable of forming a very tight alumina layer.

In air at $1000^{\circ} \mathrm{C}$ Ducropur is strongly oxidized and nitrided. The protective scales formed are not adherent and spall off with increasing thickness. 


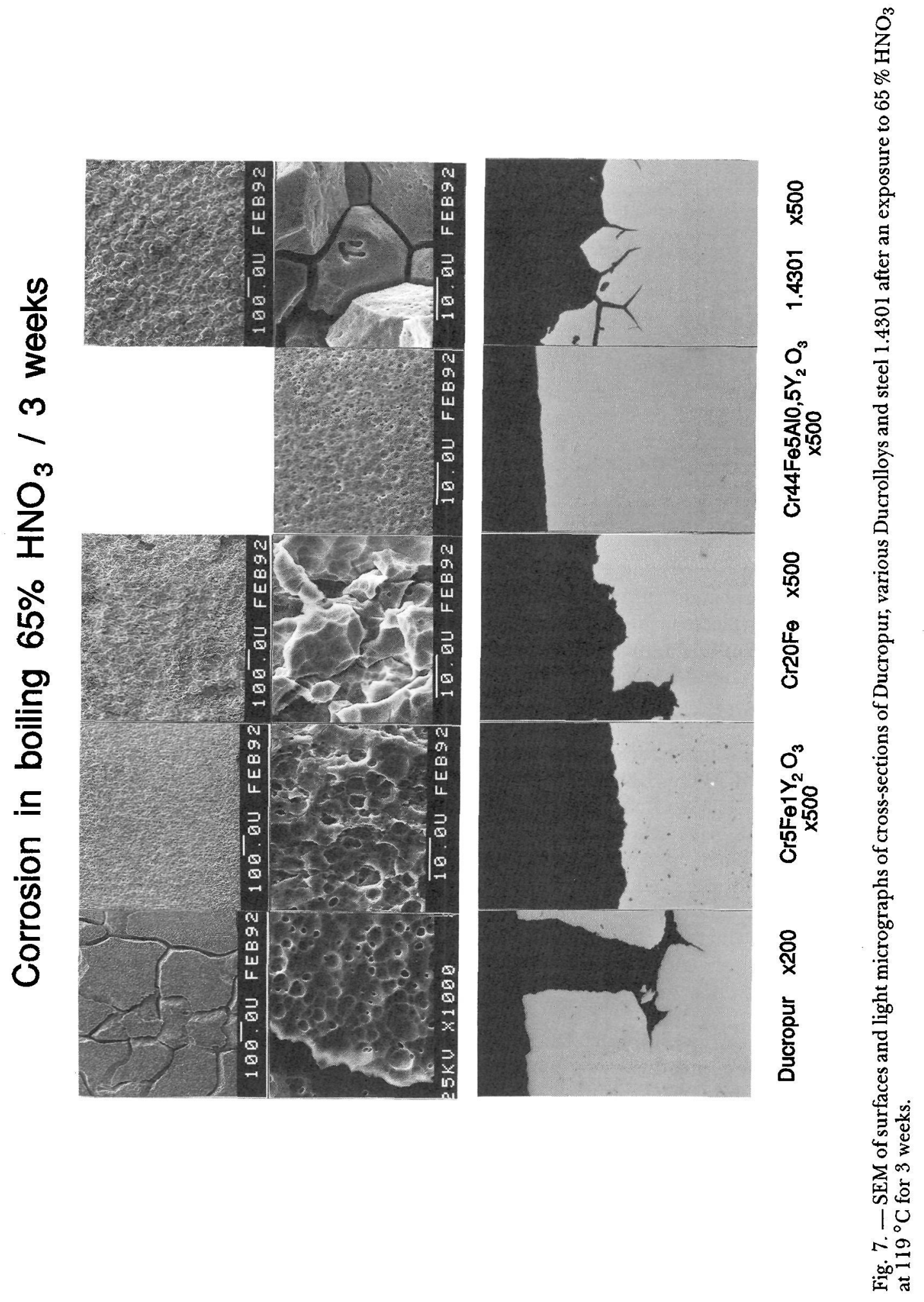




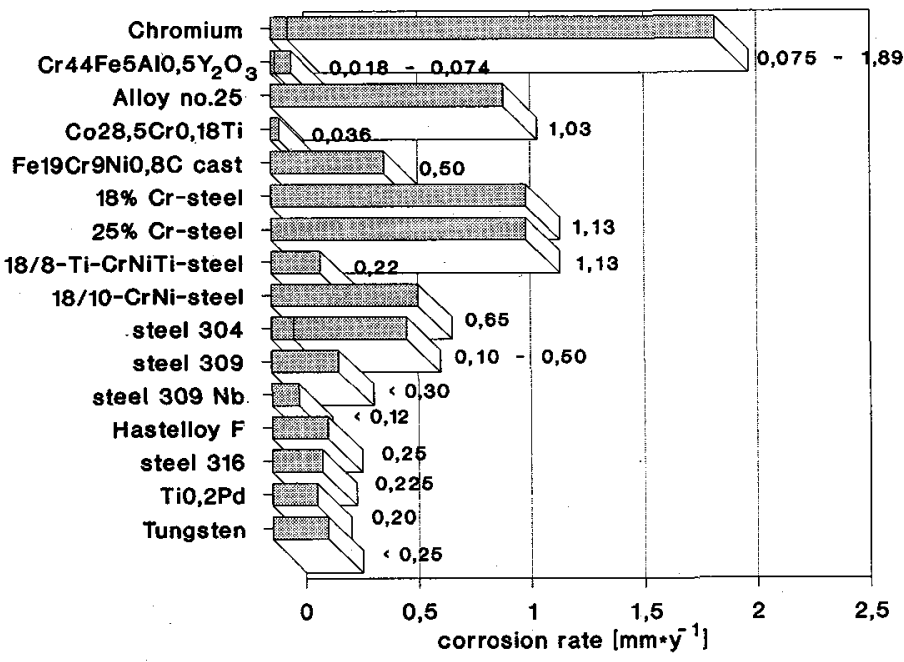

Fig. 8. - Corrosion rates of Ducropur, Ducrolloy $\mathrm{Cr} 44 \mathrm{Fe} 5 \mathrm{Al} 0.5 \mathrm{Y}_{2} \mathrm{O}_{3}$ and various alloys in boiling (119 $\left.{ }^{\circ} \mathrm{C}\right) 65 \% \mathrm{HNO}_{3}[7-17]$.

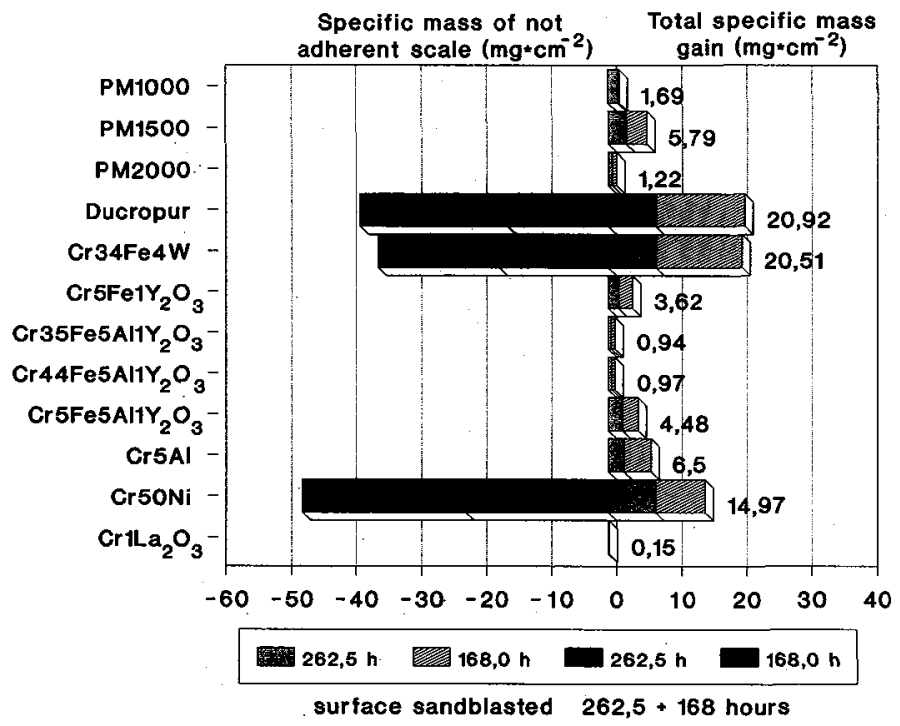

Fig. 9. - Specific mass changes of PM ODS-alloys, Ducropur and Ducrolloys in hot air at $1000^{\circ} \mathrm{C}$ for $262.5+168$ hours.

It was shown that small additions of rare earth oxides such as $\mathrm{La}_{2} \mathrm{O}_{3}$ lower the oxidation rate distinctly by stabilizing the chromia-protective layer. Furthermore, alloying with iron and aluminum $(>5 \%$ ) has a beneficial effect, owing to formation of tightly-adherent alumina scale. 

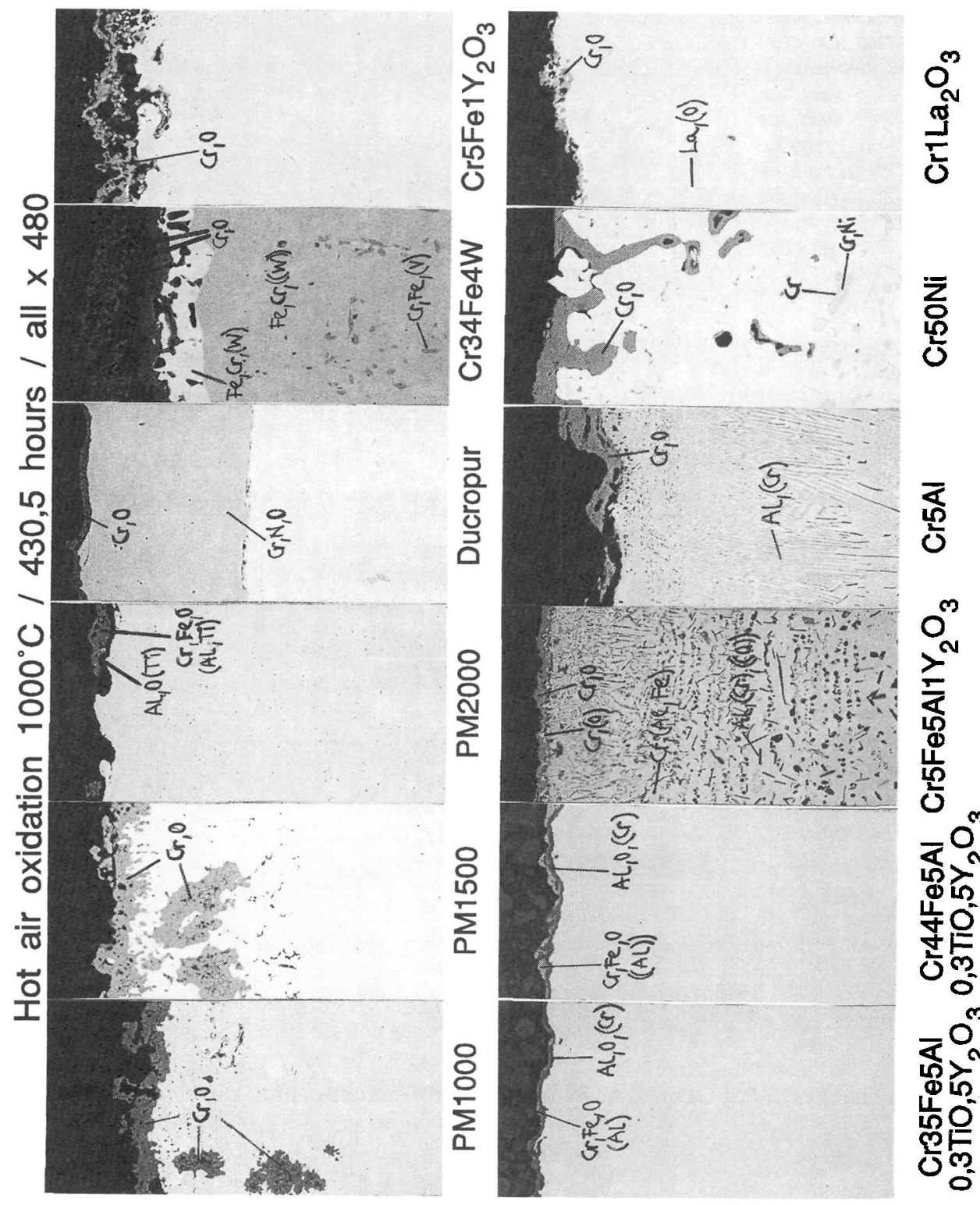

8 


\section{References}

[1] Eck R., Martinz H.-P., Sakaki T., Kato M., Mater. Sci. Eng. A120 (1989) 307-312.

[2] MARTinz H.-P. et al., Werkst. Korros. 40 (1989) 715-719.

[3] Gmelin Handbuch, Nickel, Bd. 2, 57.

[4] BecK F.A., FonTANA M.G., Corrosion 9 (1953) 287-294.

[5] SAKAKI T. et al., J.Jpn Inst. Met. 43 (1979) 527.

[6] SAKAKI T. et al., J.Jpn Inst. Met. 44 (1980) 582.

[7] Haynes Stellite Co (Kokomo/Indiana, June, 1962).

[8] Habraken L., Coutsouradis D., Kobalt 10 (1961) 3-12.

[9] HOAR T.P., Platinum Met. Rev. 5 (1961) 141-143.

[10] ZiTTER H., DECHEMA-Monogr. 45 (1962) 135-136.

[11] Pospisil R., ZeZUlová M., Werkst. Korros. 14 (1963) 633.

[12] BünGER J., Werkst. Korros. 9 (1958) 747-755.

[13] FonTANA M..G., Ind. Eng. Cehm. 45 (1953) 93A-95A.

[14] International Nickel Deutschland $\mathrm{GmbH}$, Die Korrosionsbeständigkeit der austenit. Cr-Ni-Stähle (Düsseldorf, 1963) p.30.

[15] GEE E.A. et al., Ind. Eng. Chem. 41 (1949) 1671-1672.

[16] RÜDINGER K., Werkst. Korros. 16 (1965) 112.

[17] BADGER F.S., Ind. Eng. Chem. 50 (1958) 1609. 